\title{
The Targum Of Canticles translated, with a critical introduction, apparatus, and notes by PS Alexander. The Aramaic Bible volume 17A
}

\author{
T\&T Clark \\ London-New York \\ 2003 \\ Pp. i-xxii
}

\author{
Reviewed by: \\ Johann Cook \\ Department of Ancient Studies \\ Stellenbosch University
}

\footnotetext{
$T$ he series The Aramaic Bible - the Targums - is prepared under the directorship of Martin McNamara and the editors Kevin Cathcart, Michael Maher and McNamara. The $\mathrm{Tg}$ of Canticles is already volume 17A of this series and has been prepared by the wellknown Targum scholar Philip Alexander from Manchester. The book consists of an introduction in which all relevant issues are discussed, followed by an exhaustive commentary of the targum.

In the introduction Alexander discusses various prominent issues. Available manuscripts as well as printed editions are described. The textual history of $\mathrm{Tg}$ Cant is traced and a helpful stemma is suggested. The language of this $\mathrm{Tg}$ is dealt with, as well as its argument and structure. Of special significance is the theological and exegetical themes that Alexander addresses since they provide a necessary background against which this Targum can be interpreted. Theological themes such as the exile, idolatry, righteousness, the Sanhedrin, Messianism and pacifism are referred to, whereafter Alexander deals with the targum's history of exegesis. The paragraph on the form and genre of the targum is very helpful complete with appropriate examples. The author demonstrates the application of rabbinic midrash by the Targumist and comes to the conclusion that he "almost certainly attended one of the great Talmudic schools of his day and was clearly a learned scholar with a comprehensive knowledge of Rabbinic tradition" (p. 55). The role of allegory in the interpretation is discussed. Also the fact that the Targumist included apologetic elements in Tg Cant is addressed which assists the reader to place this prominent Targum historically. Alexander is nuanced in his locating of this targum. He opts for Palestine as provenance for Tg Cant and dates it to the seventh or eighth century CE (p. 55).

In the second (large) part Alexander provides a commentary of this book based upon appropriate translations including an exhaustive list of textual and exegetical notes in a useful format. Firstly, a translation of the Hebrew text is quoted and thereafter the translation of the Targum follow. Then notes concerning these texts as well as textual variants are referred to in additional (foot)notes. In these notes the author deals with a whole array of relevant issues. These include aspects of grammar where applicable and intertextual biblical references. Relevant rabbinic parallels and general theological issues are moreover discussed. These discussions are rather exhaustive if not systematic. However, Alexander
} 
provides interesting information that is valuable to the specialist as well as the layperson. Not all scholars working on the Hebrew Bible indeed are knowledgeable in rabbinics and the author is successful in providing such information in a comprehensible way. The various appendices that are added to this commentary also add to the usefulness of the work. Finally the bibliography is exhaustive and up to date.

This volume by Alexander is an extremely important contribution to our understanding of the Hebrew Bible and its reception especially in Jewish but also in Christian circles. It is clear that Tg Cant is different from most other Tgg. It is the work of a single author who approached the Hebrew text holistically. This work is no collage but to the contrary represents a "coherent reading of the Hebrew" (p. 44) and is dealt with accordingly by Alexander in a competent manner. 